Yuriy Trykov

Professor

Volgograd State Technical University Departmant of Materials Science and

Composite Materials

Russia

\section{Leonid Gurevich}

Associate Professor Volgograd State Technical University Departmant of Materials Science and Composite Materials Russia

\section{Dmitry Pronichev}

Associate Professo Volgograd State Technical University Departmant of Materials Science and

Composite Materials Russia

Mikhail Trunov

Graduate Student Volgograd State Technical University Departmant of Materials Science and Composite Materials
Investigation of the Rupture of Ti/Steel Laminated Composite with Soft Interlayers

The study presents experimental investigations of the contact hardening effect of thin $\mathrm{Cu}$ and $\mathrm{Nb}$ interlayers in laminated Ti/Steel composites. The four layer Ti-Cu-Nb-Steel with various $\mathrm{Nb}$ and $\mathrm{Cu}$ interlayer thickness values was obtained via explosion welding and subsequently heat treated at $600^{\circ} \mathrm{C}$ for $1.5 \mathrm{hr}$. The evolution of the microstructure of the interfaces between bonded metals before and after heat treatment was studied during composites tensile loading. FEM simulation was carried out to determine the critical value of the relative interlayer thickness at which the composite tensile strength in transverse to the bond interface direction is higher than of $\mathrm{Cu}$.

Keywords: laminated composites, steel, titanium, explosion welding, interlayer, contact hardening.

\section{INTRODUCTION}

The development of energetics, space and cryogenic technology increases the demand for reliable Ti/steel adapters which can be utilized under the conditions of high pressure and extreme temperatures. During the traditional methods of Ti/steel adapters fabrication (roll welding, fuse welding) the bond interface between $\mathrm{Ti}$ and steel is heated and thus the intermetallic compound and $\mathrm{Ti}$ carbides form between welded materials. The intermetallics and carbides decrease the plasticity of the bond and cause its inoperability.

To avoid the concerns of traditional bonding methods explosion welding (EW) is usually applied to join Ti with steel [1]. Wrong EW regimes as well as the instability of the welding process during Ti/steel joints fabrication can lead to the formation of brittle molten zones in the Ti/steel interface [2]. The instability of the welding process is caused by fluctuations in stand-off distance between plates, heterogeneity of mechanical properties and geometry of the surface of the welded sheets, etc. [3].

The molten zones at Ti/steel interface are commonly presented by eutectic between $\mathrm{TiFe}$ intermetallic and $\mathrm{Ti}$ solid solution. The molten zones reduce the bond strength, decrease the contact area between steel and $\mathrm{Ti}$ and are stress concentrators. The amount of the interface area covered by molten zones after EW of Ti with steel is usually $5-8 \%$, which is considered to be acceptable [3]. However circular or needle-shape brittle molten zones adjacent to low ductility strain-hardened zones or adjacent to areas with high residual tensile stress values reduce the reliability of the bond [3]

Received: July 2015, Accepted: Septembar 2015

Correspondence to: Dr Leonid Gurevich

Volgograd State Technical University,

Lenin avenue 28, 400005 Volgograd, Russia

E-mail: mv@vstu.ru

doi:10.5937/fmet1601016T

(C) Faculty of Mechanical Engineering, Belgrade. All rights reserved
The operational heat treatments (HT) of explosion welded Ti/steel joints above $600^{\circ} \mathrm{C}$ cause the reduction of the bimetal efficiency due to the formation of the interlayer in the Ti/steel interface composed of brittle $\mathrm{TiFe}, \mathrm{TiFe}_{2}$ and $\mathrm{TiC}$ carbide compounds. The hardness of the compounds can reach $9.8-12 \mathrm{GPa}$.

Interlayer insertion between steel and $\mathrm{Ti}$ was proposed in order to avoid the intermetallic and carbide formation [4]. $\mathrm{Cu}$ (or copper alloys) and $\mathrm{Nb}$ interlayers of $1-1.5$ and $0.8-1 \mathrm{~mm}$ thickness respectively were utilized as plasticity buffer and diffusion barrier between steel and $\mathrm{Ti}$ [4]. The strength of the laminated Ti-Nb-Cu-steel composite is equal to the $\mathrm{Cu}$ strength which is $280 \mathrm{MPa}$ after EW. The strength value decreases to $200-220 \mathrm{MPa}$ after heat treatment of the composite at $600-1000^{\circ} \mathrm{C}$ due to softening of the hardened during $\mathrm{EW} \mathrm{Cu}$. One of the approaches to increase the strength of the composite is the contact hardening effect realization [5].

Mechanical properties of materials with soft interlayers depend on the relative interlayer thickness value $\chi=\delta / d$, where $\delta$ denotes the interlayer thickness and $d$ - denotes the specimen size [6]. Bakshi et. al. [79] proposed classification of composite joints with various mechanical heterogeneity as well as the equations to assess the strength value of pressure contact welded steels.

The purpose of the present study was to investigate the kinetics of the rupture processes of Ti-Nb-Cu-steel laminated composite with various $\mathrm{Cu}$ and $\mathrm{Nb}$ interlayer values and the simulation of the deformation processes of the composite.

\section{MATERIALS AND EXPERIMENTS}

In this study the explosion welded 4-layer $\mathrm{Ti}-\mathrm{Nb}-\mathrm{Cu}-$ steel composite was investigated. Chemical composition of the materials used to fabricate the composite is presented in the table 1. After EW the composite was heat treated at $600^{\circ} \mathrm{C}$ for $1.5 \mathrm{hr}$. 
Table 1. Chemical composition of the materials used in this study

\begin{tabular}{|l|c|c|c|c|c|c|c|}
\hline Material & \multicolumn{7}{|c|}{ Chemical composition, wt. \% } \\
\hline Ti layer & $\mathrm{Fe},<0.3$ & $\mathrm{C},<0.1$ & $\mathrm{Si},<0.15$ & $\mathrm{Mn}, 0.8-2$ & $\mathrm{~N},<0.05$ & $\mathrm{Al}, 3.5-5$ & $\mathrm{Zr},<0.3$ \\
\hline Nb layer & $\mathrm{C},<0.004$ & \multicolumn{2}{|c|}{$\mathrm{N},<0.005$} & \multicolumn{2}{c|}{$\mathrm{O},<0.0015$} & \multicolumn{2}{c|}{$\mathrm{H},<0.0008$} \\
\hline Cu layer & $\mathrm{Fe},<0.005$ & $\mathrm{Ni},<0.02$ & $\mathrm{~S},<0.004$ & $\mathrm{As},<0.002$ & $\mathrm{~Pb},<0.005$ & $\mathrm{Zn},<0.004$ & $\mathrm{O},<0.05$ \\
\hline Steel layer & $\mathrm{C},<0.12$ & $\mathrm{Si},<0.8$ & $\mathrm{Mn},<2$ & $\mathrm{Ni}, 9-11$ & $\mathrm{Cr}, 17-19$ & $\mathrm{~S},<0.02$ & $\mathrm{Cu},<0.3$ \\
\hline
\end{tabular}

Table 2. Deformation of the layers of the composite at various relative thickness $\mathrm{cu}_{u}$ values

\begin{tabular}{|c|c|c|c|c|c|c|c|c|}
\hline \multirow{3}{*}{ No } & \multirow{3}{*}{$\begin{array}{l}\text { Composite } \\
\text { layer }\end{array}$} & \multirow{3}{*}{$\begin{array}{l}\text { Load value, } \\
P_{\text {rupt }} \text { fraction }\end{array}$} & \multicolumn{6}{|c|}{ Layer deformation at various $\chi_{C u}$ values } \\
\hline & & & \multicolumn{2}{|c|}{$\chi_{C u}=0.5$} & \multicolumn{2}{|c|}{$\chi_{C u}=0.067$} & \multicolumn{2}{|c|}{$\chi_{C u}=0.033$} \\
\hline & & & After EW & After HT & After EW & After HT & After EW & After HT \\
\hline 1 & \multirow{2}{*}{$\mathrm{Ti}$} & $0.8-0.9$ & 0 & 0 & 0 & 0 & 0 & 0 \\
\hline 2 & & 1.0 & 0 & 0 & 0 & 0 & 0 & 0 \\
\hline 3 & \multirow{2}{*}{$\mathrm{Nb}$} & $0.8-0.9$ & 15 & - & 60 & - & 0.5 & 0 \\
\hline 4 & & 1.0 & 39 & 13 & 60 & 40.5 & 1 & 1.5 \\
\hline 5 & \multirow{2}{*}{$\mathrm{Cu}$} & $0.8-0.9$ & 85 & - & 40 & - & 1.5 & 2.5 \\
\hline 6 & & 1.0 & 50 & 84 & 17 & 39 & 2.0 & 3.0 \\
\hline 7 & \multirow{2}{*}{ Steel } & $0.8-0.9$ & 0 & - & 0 & - & 98.0 & 97.5 \\
\hline 8 & & 1.0 & 11 & 3 & 23 & 20.5 & 97 & 95.5 \\
\hline
\end{tabular}

In order to study the impact of microstructure, shape and size of the inter-metallic compound, as well as width of $\mathrm{Cu}$ and $\mathrm{Nb}$ inter-layers on the kinetics of rupture processes of explosion welded multi-layer composites, the specimen (with $3 \times 6 \mathrm{~mm}$ transition area dimensions) was loaded transversely to the bond. The maximum load was $20 \mathrm{kN}$. During the loading, specimen microstructure was investigated via an optical system with $\times 1500$ magnification. The deformation and the origins of material rupture in the bond interface after EW and after subsequent heat treatment were investigated.

Strain gauges were applied and reference lines were plotted on the composite surface to study the elongation and strain-stress state in the researched materials.

No microstructure change was observed under the loads lower than $60-70 \%$ of the load at which rupture of the composite was observed $P_{\text {rupt }}$ for all considered values of $\chi_{\mathrm{Cu}}$. Thus the microstructure and deformation of composite layers evolution was studied at two loads: $P=(0.8 \ldots 0.9) P_{\text {rupt }}$ and $P=P_{\text {rupt }}$.

\section{RESULTS AND DISCUSSION}

Metallographic study of the multilayered $\mathrm{Ti}-\mathrm{Nb}-\mathrm{Cu}-$ steel composite after $\mathrm{EW}$ and subsequent heat treatment at $600^{\circ} \mathrm{C}$ for $1.5 \mathrm{hr}$ revealed the sequence according to which the layers were involved into plastic deformation during tensile load. The influence of local inclusions of phases formed at bond interfaces at various $\chi \mathrm{Cu}$ values was determined.

No observable deformation (elongation was measured) of the Ti layer (table 2) of the composite was identified at various relative thickness values of $\mathrm{Cu}$ and $\mathrm{Nb}$ interlayers in the whole range of applied loads. The deformation of the steel layer depended on the applied load, the condition of the material and relative thickness value of $\mathrm{Cu}$ interlayer. The steel layer significantly deformed at load $P=(0.8 \ldots 0.9) P_{\text {rupt }}$ in the adjacent to $\mathrm{Cu}$ area at $\chi_{C u}=0.067$. Heat treatment of the composite at $600^{\circ} \mathrm{C}$ reduced the amount of steel subjected to deformation, however local character of the deformation retained.

When $\chi_{C u}=0.033$ the uniform deformation of steel was observed. At $P=P_{\text {rupt }}$ the deformation of steel was 97\% after EW and $95.5 \%$ after EW and subsequent heat treatment.

During the loading at $P=(0.8 \ldots 0.9) P_{\text {rupt }}$, the deformation was mainly observed in the $\mathrm{Cu}$ interlayer and was $85 \%$ and $40 \%$ for $\chi_{C u}=0,5$ and $\chi_{C u}=0.067$ respectively. At $\chi_{C u}=0.033$ (minimum $\mathrm{Cu}$ interlayer thickness value) slight deformation of $\mathrm{Cu}$ in the areas adjacent to steel and $\mathrm{Nb}$ was observed, while the origins of rupture were identified in steel. The adjacent to steel and $\mathrm{Nb}$ areas of $\mathrm{Cu}$ have highest contact stress values. At $P=P_{\text {rupt }}$ the deformation of $\mathrm{Cu}$ interlayer remains unchanged, while the rupture of the composite was observed in steel layer. Common relation between deformation and relative thickness value was observed for $\mathrm{Nb}$ interlayer $\chi_{N b}$.

Molten zones at the interface between $\mathrm{Ti}$ and $\mathrm{Nb}$ did not visibly impact the crack formation as well as the rupture behavior of the composite in the whole range of investigated relative thickness $\chi_{C u}$ values. During the loading at $P=(0.8 \ldots 0.9) P_{\text {rupt }}$ when $\chi_{C u}=0.067$ small cracks and micro ruptures were formed in the molten zones between $\mathrm{Cu}$ and $\mathrm{Nb}$. Molten zones between $\mathrm{Cu}$ and $\mathrm{Nb}$ had $2.5 \mathrm{GPa}$ hardness value. However the formed cracks and ruptures did not make a crucial impact on the final rupture of the material.

The $\mathrm{Cu} /$ steel interface had molten zones with 2.8 $\mathrm{GPa}$ hardness value. When the thickness of $\mathrm{Cu}$ interlayer was high $\left(\chi_{C u}=0.5\right)$ the molten zones became the origins of cracks. However the cracks were terminated by plastic $\mathrm{Cu}$, while the rupture of the composite was observed in the soft $\mathrm{Cu}$ interlayer where the 3-dimensional stress state mainly occurred.

The reduction of $\mathrm{Cu}$ interlayer thickness down to $\chi_{C u}=0.067$ contributed to the decrease of the interlayer deformation, while the molten zones at the $\mathrm{Cu} /$ steel and 


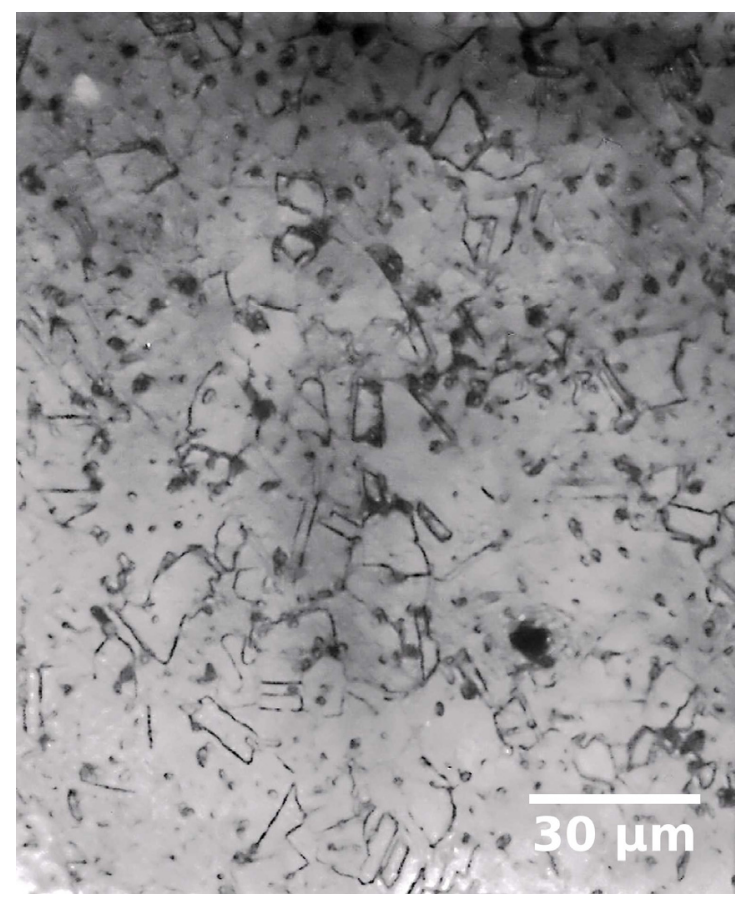

(a)

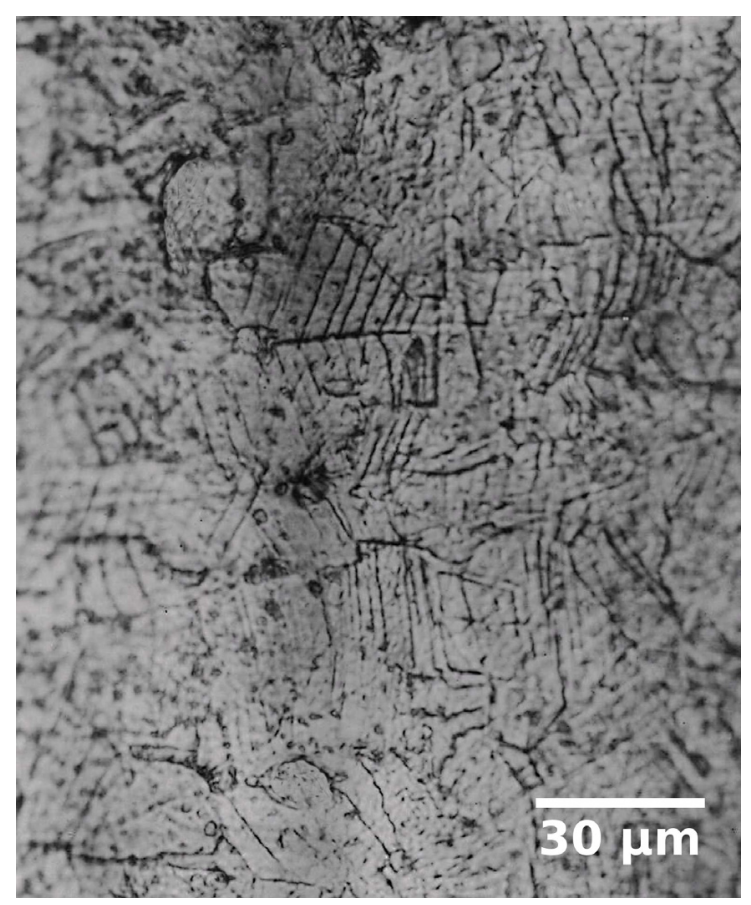

(b)

Figure 1. Microstructure of $\mathrm{Cu}(\mathrm{a})$ before rupture and (b) after rupture

$\mathrm{Cu} / \mathrm{Nb}$ interfaces became the origins of material rupture and critical stress values.

Microstructure investigations of the composite deformation behavior and rupture evolution during tensile tests has revealed the initial plastic deformation at $\chi_{C u}=0.5$ to occur in $\mathrm{Cu}$ interlayer along the $\mathrm{Cu} / \mathrm{steel}$ and $\mathrm{Cu} / \mathrm{Nb}$ interface. Subsequent plastic deformation progresses in the central part of $\mathrm{Cu}$ interlayer and increases the initial number (figure 1b) of twin boundaries (figure 1a) and slip bands, which consequently results in $\mathrm{Cu}$ interlayer rupture with $\mathrm{Nb}$ interlayer plastic deformation.

Investigation of the plotted on $\mathrm{Cu}$ interlayer reference line geometry evolution revealed the initial deformation of $\mathrm{Cu}$ interlayer to be along the load direction and subsequent radial compression at the moment of neck formation.

$\mathrm{Nb}$ interlayer deformation was observed in the areas adjacent to $\mathrm{Cu} / \mathrm{Nb}$ and $\mathrm{Ti} / \mathrm{Nb}$ interface, thus Ti prevents $\mathrm{Nb}$ interlayer from large deformation. The increase in the load value contributes to intense deformation of the central part of $\mathrm{Nb}$ interlayer. The deformation spreads along parallel surfaces transversely to load direction. When $\chi_{C u}=0.5$ steel gets involved into deformation only with the waves, which occurred during EW. Steel deforms due to intense $\mathrm{Cu}$ interlayer deformation. The lack of change in reference line plots on Ti up until the rupture stress is reached reveals the absence of plastic deformation in $\mathrm{Ti}$ in the whole studied range of $\chi_{\mathrm{Cu}}$.

Heat treatment at $600^{\circ} \mathrm{C}$ for $1.5 \mathrm{hr}$ did not visibly influence the deformation behavior of the composite. However, after heat treatment plastic deformation was observed at lower stress values due to recrystallization of $\mathrm{Cu}$ and thus reduction of stress in the bond.

At $\chi_{C u}=0.067$ more intense flow of $\mathrm{Nb}$ was observed and the increased number of slip bands in steel identified its deformation. However the EW defects (gaps, molten zones) contributed to the rupture of $\mathrm{Cu}$ interlayer in this case.

The decrease in $\chi_{C u}$ down to 0.03 resulted in the realization of contact hardening on both $\mathrm{Cu}$ and $\mathrm{Nb}$ interlayers. The tensile strength of the interlayers was higher than of steel. The origins of rupture were inclusions like carbides and alloying elements in the adjacent to $\mathrm{Cu}$ steel area. The microcracks developed from the origins of rupture and merged in macro crack during the final stage of steel rupture. Heat treatment of the material did not change the deformation behavior.

The behavior of the $\mathrm{Ti} / \mathrm{Nb} / \mathrm{Cu} / \mathrm{Steel}$ composite under tensile loads was simulated via Simulia/Abaqus software. Materials' plasticity was simulated according to JonsonCook model [10] and the yield strength is given by:

$$
\sigma_{Y}=\left(A+B \cdot \varepsilon_{p}^{n}\right)\left(1+\ln \frac{\dot{\varepsilon}_{p}^{n}}{\dot{\varepsilon}_{0}}\right)\left[1-\left(\frac{T-T_{r}}{T_{m}-T_{r}}\right)^{m}\right]
$$

where $\varepsilon_{p}$ - accumulated plastic strain, $\dot{\varepsilon}_{p}$ - plastic strain rate, $\dot{\varepsilon}_{p}$ - reference strain rate, $T$ - current temperature, $T_{r}$ - room temperature, $T_{m}$ - melting temperature, $A, B$, $C, n$ and $m-$ model constants. $\sigma_{Y}$ denotes the hardening function of the material. Material rupture was considered using Jonson-Cook rupture model [11]. Finite element breaking occurs when $D=1$ :

$$
D=\frac{1}{\varepsilon_{f}} \sum_{i} \varepsilon_{p}^{i}
$$

where

$$
\begin{aligned}
& \varepsilon_{f}=\left[D_{1}+D_{2} \exp \left(D_{3} \cdot \frac{p}{\sigma_{e f}}\right)\right] \times \\
& \times\left(1+D_{4} \ln \frac{\varepsilon_{p}}{\varepsilon_{0}}\right) \times\left[1+D_{5}\left(\frac{T-T_{r}}{T_{m}-T_{r}}\right)\right]
\end{aligned}
$$




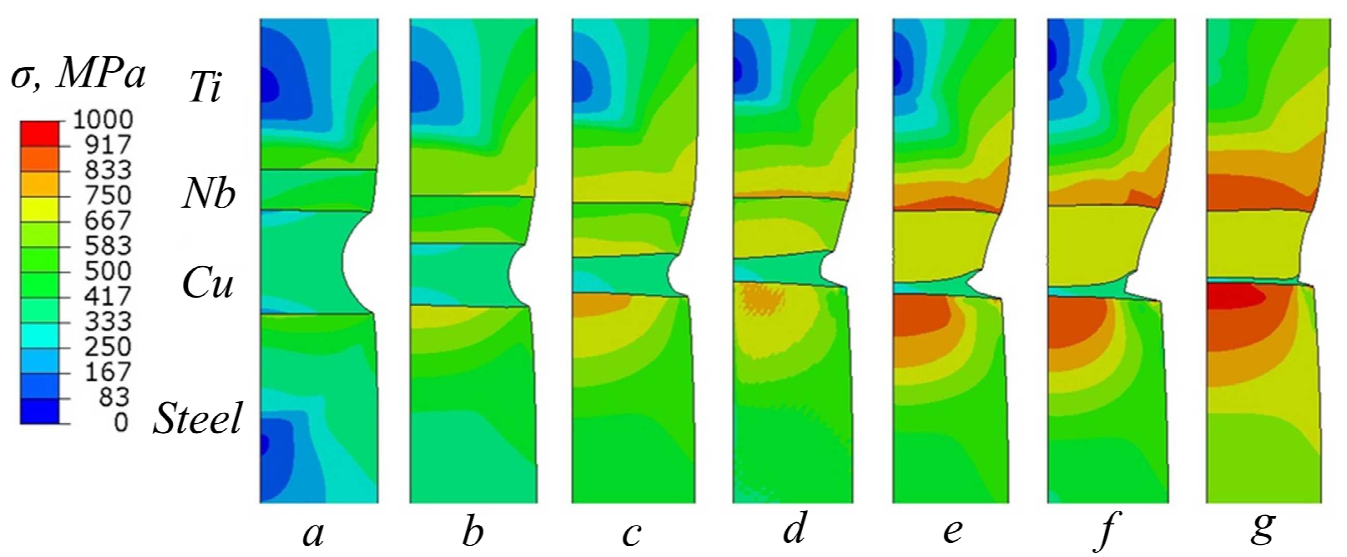

Figure 2. Von Mises Stress distribution at ${ }_{N b}=0.166$ and: (a) $c_{u}=0.267$, (b) $c_{u}=0.167$, (c) $c_{u}=0.1$, (d) $c_{u}=0.067,(\mathrm{e}) c_{u}=0.033$, (f) $c_{u}=0.027,(g) \quad c_{u}=0.013$.
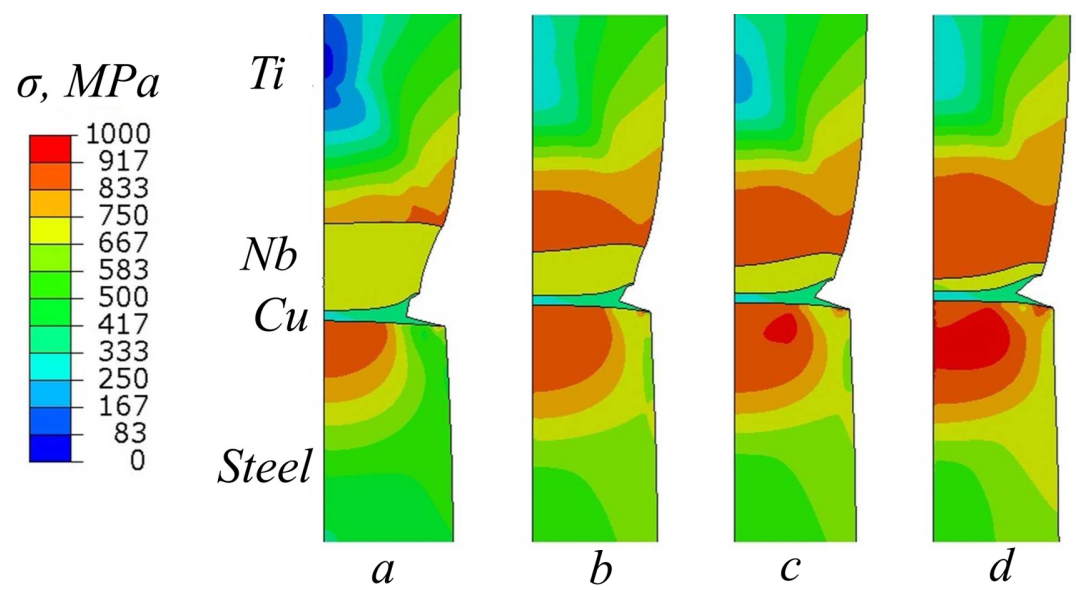

Figure 3. Von Mises Stress distribution at $c_{u}=0.0266$ and: (a) ${ }_{N b}=0.166$, (b) ${ }_{N b}=0.1$, (c) ${ }_{N b}=0.066$, (d) ${ }_{N b}=0.033$.

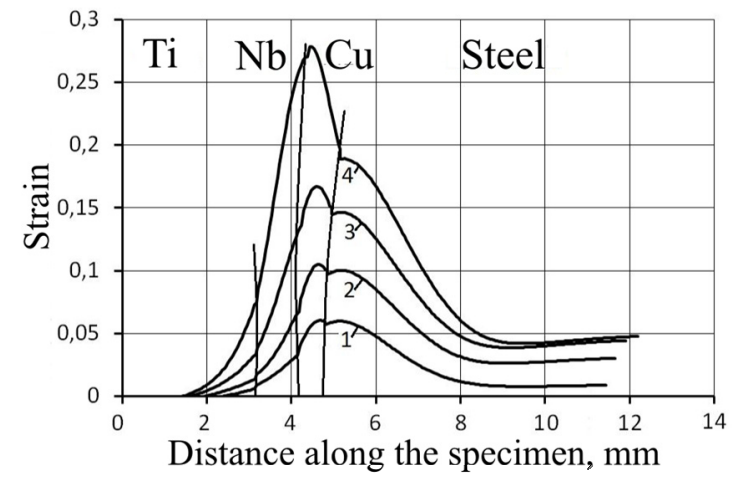

(a)

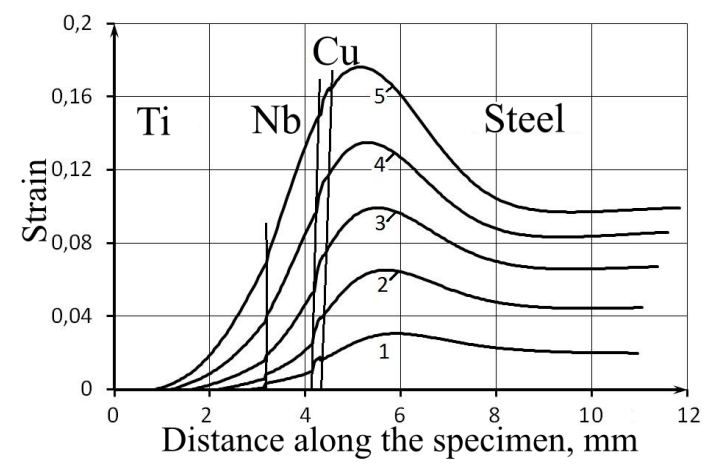

(c)

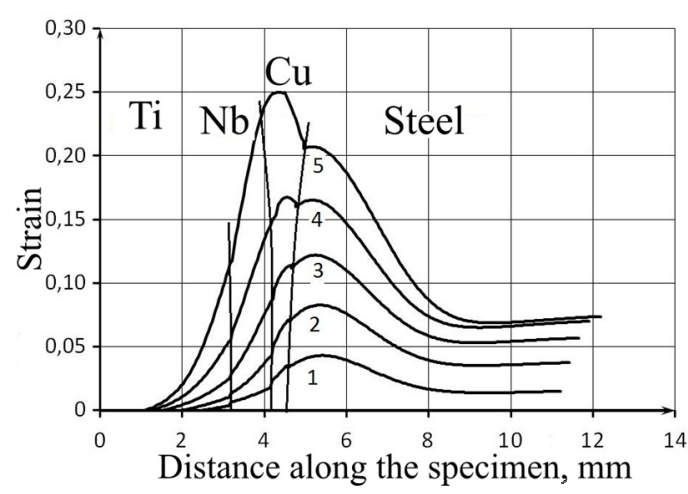

(b)

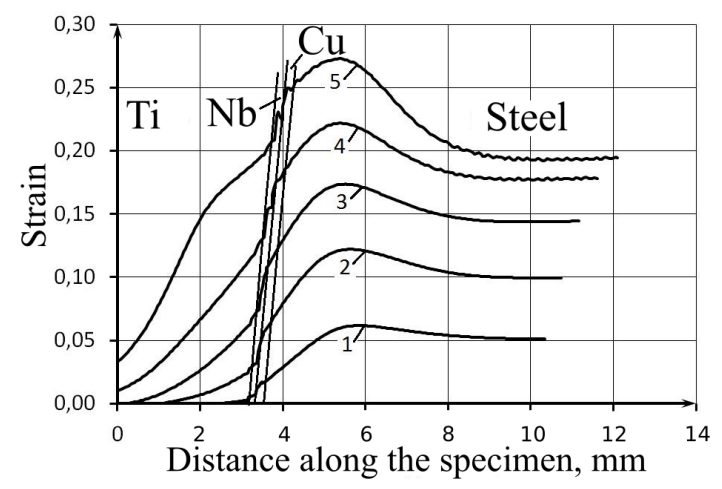

(d)

Figure 4. Strain value distribution across the composite at various values of $c_{u}$ and ${ }_{N b}$ : (a) ${ }_{N b}=0.167$ and $c_{u}=0.1,(b){ }_{N b}=0.167$ and $c_{u}=0.067$, (c) ${ }_{N b}=0.167$ and $c_{u}=0.027$, (d) ${ }_{N b}=0.033$ and $C_{c}=0.027$. Specimen deformation: $1-0.3 \mathrm{~mm}, 2-0.6 \mathrm{~mm}, 3-0.9$ $\mathrm{mm}, 4-1.2 \mathrm{~mm}, 5-1.5 \mathrm{~mm}$. 


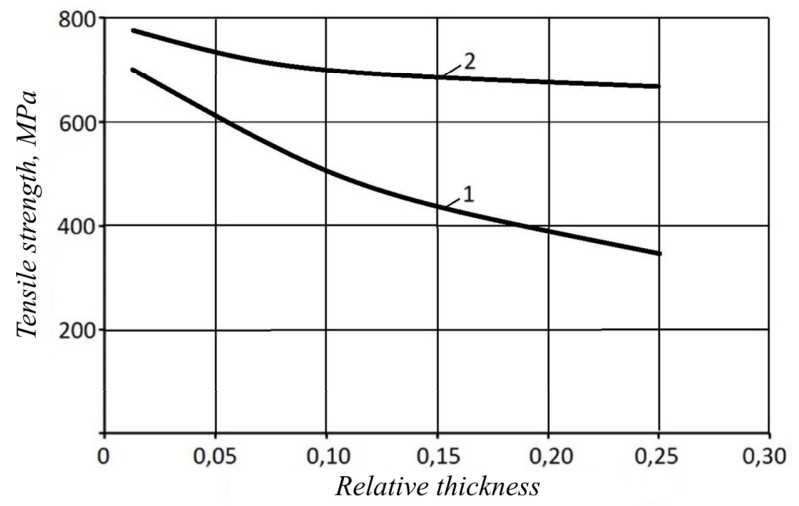

Figure 5. The relation between tensile strength of the composite in transverse to the material interface direction and (1) $C u, N b=0.167,(2) \quad N b, C u=0.027$.

The parameters taken into consideration in this study materials were observed in [12-15]. The impact of the speed of deformation was not considered in this study. The strength value of the bond between layers was considered equal to the strength of the weakest layer in the bond.

The simulation revealed the change in the composite deformation and rupture character at various $\chi_{C u}$ values $\left(\chi_{N b}=0.166\right)$. The simulation results are presented on figure 2 . In the range of $\chi_{C u} \geq 0.026$ the rupture of the composite was observed in the $\mathrm{Cu}$ interlayer. The reduction of $\mathrm{Cu}$ interlayer thickness contributed to the increase of plastic deformation in $\mathrm{Nb}$ and emergence of plastic deformation in $\mathrm{Ti}$ and steel in the adjacent to the interface areas. In the range where $\chi_{\mathrm{Cu}} \leq 0.026 \mathrm{Cu}$ and $\mathrm{Nb}$ interlayers are deformed equally (figure $2 \mathrm{~g}, 4 \mathrm{c}$ ).

The reduction of $\chi_{N b}\left(\chi_{C u}\right.$ was considered constant and equal to 0.027) did not result in the rupture of steel or Ti layers, however the areas with high stress value in $\mathrm{Ti}$ and steel were increasing in size (figure 3, 4d). The reduction of both $\mathrm{Nb}$ and $\mathrm{Cu}$ relative thickness ratio values contributed in the growth of stress value and resulted in the rupture of the composite.

As shown in figure 5 the calculated via simulation stress values and experimentally obtained results are in good convergence.

\section{CONCLUSION}

The deformation behavior of Ti steel laminated metal composite under tensile loads was identified. The influence of molten zones on the deformation and rupture behavior of multilayered composite was investigated. The possible approach to reduce the total plastic deformation of the multilayered composite was proposed.

The simulation of tensile load of multilayered $\mathrm{Ti} / \mathrm{Nb} / \mathrm{Cu} / \mathrm{Steel}$ laminated composite allowed determining the conditions when the plastic deformation is transferred on the steel layer.

\section{ACKNOWLEDGMENT}

The present study was carried out according to the assignment of Russian Ministry of Education No 11.1865.2014/K.

\section{REFERENCES}

[1] McKenney, C.R. and Banker, J.G.: Explosionbonded metals for marine structural applications, Marine Technology Society Journal, Vol. 8, No. 3, pp. 285-292, 1971.

[2] Song, J., Kostka, A., Veehmayer, M., and Raabe, D.: Hierarchical microstructure of explosive joints: Example of titanium to steel cladding, Materials Science and Engineering: A, Vol. 528, No. 6, pp. 2641-2647, 2011.

[3] Lysak, V. I. and Kuzmin S. V.: Explosive welding of metal layered composite materials, The E. O. Paton electric welding institute of the National Academy of Science of Ukraine, Kiev, 2003.

[4] Belousov, V.P., Sedykh, V.S. and Trykov, Yu.P.: Mechanical Properties of Ti-Steel Welds with Intermediate Layers Obtained by Explosion Welding, Svar. Ppoizv., No. 9, pp. 19-21, 1971.

[5] Gurevich, L.M., Trykov, Yu.P., Pronichev, D.V. and Trunov, M.D.: Investigation on the contact hardening of $\mathrm{Al} / \mathrm{Steel}$ laminated composites with soft interlayers, WSEAS Transactions on Applied and Theoretical Mechanics, Vol. 9, pp. 275-281, 2014.

[6] Trykov, Yu.P. et al.: Sloistye kompozity na osnove alyuminiya $i$ yego splavov, Metallurgizdat, Moscow, 2004.

[7] Bakshi, O.A., Erofeev, V.V., Shakhmatov, M.V., Iaroslavtsev, S.I. and Anisimov, I.: Effect of the degree of mechanical heterogeneity on the static strength of welded joints, Welding Production, Vol. 30, pp. 5-8, 1983.

[8] Gnyp, I.P., Bakshi, O.A., Pokhmurskii, V. I., and Shron, R.Z., Determining the fracture toughness of low-strength metals. Materials Science, Vol. 11 No. 2, pp. 176-179, 1975.

[9] Ostsemin, A.A. and Dil'man, V.L., Compression of a plastic layer by two rough plates, Strength of Materials, Vol. 22, No. 7, pp. 1076-1085, 1990.

[10] Johnson, G.R. and Cook, W.H.: A constitutive model and data for metals subjected to large strains, high strain rates and high temperatures, in Proceedings of the 7th International Symposium on Ballistics, 04.1983, Vol. 21, pp. 541-547.

[11] Johnson, G.R. and Cook, W.H.: Fracture characteristics of three metals subjected to various strains, strain rates, temperatures and pressures, Engineering fracture mechanics, Vol. 21, No. 1, pp. 31-48, 1985.

[12] Kay, G.: Failure modeling of titanium-61-4V and 2024-T3 aluminum with the Johnson-Cook material model, Technical Rep., Lawrence Livermore National Laboratory, Livermore, CA, 2002.

[13] Gambirasio, L. and Rizzi, E.: On the calibration strategies of the Johnson-Cook strength model: discussion and applications to experimental data, Materials Science and Engineering: A, Vol. 610, pp. 370-413, 2014. 
[14] Holmquist, T.J. and Johnson, G.R.: Determination of constants and comparison of results for various constitutive models, Le Journal de Physique IV, Vol. 1, No. C3, pp. 853-860, 1991.

[15] Ikkurthi, V.R. and Chaturvedi, S.: Use of different damage models for simulating impact-driven spallation in metal plates, International journal of impact engineering, Vol. 30, No. 3, pp. 275-301, 2004.

\section{ИСТРАЖИВАЊЕ ПОЈАВЕ ПУКОТИНА КОД ЛАМЕЛАРНОГ КОМПОЗИТА ОД ТИТАНИЈУМА И ЧЕЛИКА СА МЕКАНИМ МЕЪУСЛОЈЕВИМА}

\section{Јуриј Триков, Леонид Гуревич, Дмитриј Проничев, Михаил Трунов}

Рад приказује експериментална истраживања утицаја контактног стврдњавања танких међуслојева од $\mathrm{Cu}$ и $\mathrm{Nb}$ код ламеларног композита од Тi и/или челика. Четворослојни композит састављен од $\mathrm{Ti}-\mathrm{Cu}-\mathrm{Nb}$-челика са међуслојевима, различитих вредности дебљине, од $\mathrm{Nb}$ и $\mathrm{Cu}$ добијени су експлозивним заваривањем и накнадном термичком обрадом на $600^{\circ} \mathrm{C}$ у трајању од 1,5 сата. Проучавање развоја микроструктуре везивног композита између спојених метала пре и после термичке обраде обављено је оптерећењем композита на затезање. ФЕМ симулацијом одређена је критична вредност релативне дебљине међуслоја, при којој је затезна чврстоћа композита у попречном правцу везивног композита већа него код $\mathrm{Cu}$. 